\title{
Development and destruction of the first state funded anti-smoking campaign in the USA
}

\author{
T H Tsoukalas, S A Glantz
}

Tobacco Control 2003;12:214-220

See end of article for authors' affiliations

....................

Correspondence to: Professor Stanton A Glantz, PhD, Box 0130, University of California San

Francisco, San Francisco, California CA 94143,

USA;

glantz@medicine.ucsf.edu

Received 14 June 2002 Accepted 23 March 2003
Background: Minnesota was the first state in the USA to implement a large state funded tobacco control programme (in 1985). Despite evidence of effectiveness, it was dismantled in 1993.

Objective: To describe and analyse how and why these events transpired and identify lessons for tobacco control advocates facing similar challenges in the 21 st century.

Design: Case study based on previously secret tobacco industry documents, news reports, research reports, official documents, and interviews with health advocates and state government officials.

Results: Unable to defeat funding for this campaign in 1985, the tobacco industry organised groups which eliminated it later. Despite the programme's documented effectiveness, it was dismantled based on claims of fiscal crisis. These claims were not true; the real debate was what to do with the state's surplus. Health advocates failed to challenge the claim of fiscal crisis or mobilise public support for the programme.

Conclusions: Simply quoting evidence that a tobacco control programme is effective does not ensure its continuing survival. Claims of fiscal crisis are an effective cover for tobacco industry efforts to dismantle successful programmes, particularly if health advocates accept these claims and fail to mobilise political pressure to defend the programme.
T he era of large state funded tobacco control programmes seems to have started in the USA when California increased its tobacco taxes in 1988 and allocated $20 \%$ of the money to anti-tobacco education, ${ }^{12}$ an idea which then spread to other states. ${ }^{3-9}$ This model spread further when the Master Settlement Agreement, which ended state litigation against the tobacco industry in exchange for substantial payments to the states, made funds potentially available for tobacco control and created the American Legacy Foundation $^{10}$ to run a national tobacco control programme. These programmes include anti-smoking media campaigns that, when done properly, reduce tobacco consumption. ${ }^{11-17}$ The tobacco industry, directly or through surrogates, has been opposing these campaigns, often citing government budgetary constraints or competing priorities. ${ }^{29}{ }^{14} 18$ These battles echo the situation in Minnesota-which actually had the first state funded tobacco control campaign between 1984 and 1994, when the first state funded anti-smoking campaign was developed and then destroyed.

Minnesota was an early leader in tobacco control. In 1974, Monticello, Minnesota created "D-Day", the first "Don'tsmoke Day" in the USA, two years before the first American Cancer Society "Great Smokeout". ${ }^{19}$ In 1975, the Minnesota Legislature enacted its Clean Indoor Air Act, which required creation of non-smoking sections, a strong public health policy for its time. Then, in 1984, the Minnesota Department of Health published the Minnesota Plan for Nonsmoking and Health (Minnesota Plan), which included the first state funded anti-smoking media campaign. The tobacco industry immediately recognised the dangerous precedent that had been set, expanded its political efforts in Minnesota, and eventually destroyed the campaign. The tobacco industry succeeded mainly because health advocates failed to defend the campaign against claims of a budget crisis and because the Department of Health underestimated the power of the tobacco industry and its Minnesota based lobbying force.

\section{METHODS}

Data were gathered from interviews with health advocates and state officials; news reports, research reports, and Minne- sota state and federal government documents; and tobacco industry documents from the internet (available through www.tobaccoarchive.com, especially the Tobacco Institute site www.tobaccoinstitute.com, and the Legacy Tobacco Documents Library at the University of California, San Francisco, legacy.library.ucsf.edu). Search terms included "Minnesota plan", "antismoking campaign", "Minnesota strategy", "Minnesota plan for nonsmoking and health", "HYD", "budget", "expenditure", and names of numerous tobacco industry officials, lobbyists, allies, and related organisations. Searches were done between 1 February 2001 and 14 May 2002.

Interviews were conducted in accordance with a protocol approved by the University of California, San Francisco committee on human research. We conducted 15 telephone and three on site interviews with former planners and administrators of the programme under study, leaders from statewide health volunteer organisations and their coalition, and journalists. Each interview lasted between 45-60 minutes. Follow up interviews lasted between 15-30 minutes. Potential interviewees were sent a letter indicating the purpose of the study and the ground rules for the interview. Once the potential interviewee agreed to participate the taped record of the interview was transcribed for analysis. We used the snowball technique for identifying interviewees. No one refused to participate.

Data on campaign contributions and lobbying expenditures were obtained from the Minnesota Ethical Practices Board, later named the Campaign Finance and Public Disclosure Board.

\section{RESULTS}

The Minnesota Plan for Nonsmoking and Health

In November 1983, the Minnesota Commissioner of Health, Sr Mary Madonna Ashton, appointed a broad based Technical

Abbreviations: ANSR, Association for Nonsmokers Rights; HYD, Helping Youth Decide; HYSN, Helping Youth Say No; IBEW, International Brotherhood of Electrical Workers; MMA, Minnesota Medical Association; UFCW, United Food and Commercial Workers International Union 
Advisory Committee on Nonsmoking and Health ${ }^{20}$ consisting of leaders from business, labour, health, and education and charged it with producing a statewide plan to promote non-smoking through public communications, youth education, public and private regulatory policies, and economic incentives and disincentives. ${ }^{20}$ This committee was broadly constituted to represent many constituencies so that the resulting report could be expected to have and maintain broad political support. The committee's report, submitted in September 1984, the "Minnesota Plan for Nonsmoking and Health", proposed "a coordinated statewide program to prevent young people from starting to smoke, to encourage and assist smokers to quit, and to promote clean indoor air". ${ }^{20}$

The plan included the first state funded anti-smoking media campaign in the USA, which was to use social marketing principles and "be carefully coordinated with regulatory, economic, and health-information measures". ${ }^{20}$ Although the committee did not propose dollar amounts, it recommended that "funding needs for the promotion of nonsmoking should be obtained from multiple sources including legislative appropriation".$^{20}$ Eventually, funding for the first media campaign originated from a March 1985 Department of Health proposed cigarette tax increase of 7 cents.

The tobacco industry's response to the Minnesota Plan The tobacco industry used a combination of five responses to defend itself against the Minnesota Plan. First, the Tobacco Institute, the tobacco industry's political and lobbying arm in the USA, monitored the committee from its creation in November 1983. ${ }^{21}$ While the tobacco industry was unsuccessful in influencing the work and recommendations of the committee, ${ }^{22}$ monitoring the committee permitted the industry to recognise the magnitude of the Minnesota Plan and the Department of Health's ability to implement the committee's recommendation, which led the industry to implement additional responses.

Second, on 25 September 1984, the Tobacco Institute recognised that the Minnesota Plan (published 14 September 1984) would have national significance and "significant policy, marketing, legislative and economic ramifications", ${ }^{21}$ so it introduced its own "youth tobacco prevention" programme, titled "Helping Youth Decide" (HYD). ${ }^{23}{ }^{24}$ The implication was that the anti-smoking media campaign of the Minnesota Plan would be duplicating its own national advertisements to discourage youth from smoking. ${ }^{24}{ }^{25}$ By 1991, and while the Minnesota Plan's media campaign was still in operation, a close variant of the HYD campaign called Helping Youth Say No, (HYSN), received the endorsement of the Catholic Archbishop of St Paul/Minneapolis and was recommended for use in Minnesota Catholic school districts. ${ }^{26}$

Third, Tobacco Institute officials prepared to fight the introduction of legislation to implement the advisory committee's recommendations. ${ }^{25} 27$

Fourth, in September 1984, the tobacco industry developed a two tier strategy to destroy the Minnesota Plan, claiming that it was "unnecessary, expensive, and impractical". ${ }^{25}$ The first strategy was to attack the plan's underlying research. The tactics were to use estimates from advertising and public relations firms to demonstrate that the Health Department's estimated costs for the campaign were too low so that much more taxpayer money would be needed to implement the programme, and to promulgate these cost estimates by using third parties through a Minnesota business and labour coalition. ${ }^{25}$ Businesses under consideration for membership in the tobacco industry's anticipated coalition against the Minnesota Plan included Pillsbury, 3M, Honeywell, Northwest Orient Airlines, Cargill and Blue Cross/Blue Shield. Labour unions included from United Food and Commercial Workers International Union (UFCW), Steelworkers, and International Brotherhood of Electrical Workers (IBEW), to the American
Federation of Teachers and International Association of Machinists. By the late 1980s, industry had successfully recruited a Teamsters Union official to lobby on its behalf at the Minnesota Capitol. ${ }^{28}$ The second strategy was to shift the debate away from health to "areas in which we have the most credible arguments, e.g., economics, government intervention, etc $^{\prime 25}$ using editorial roundtables with representatives from Minnesota businesses, labour, education, and police groups, in order to assess from an individual point of view "the negative effects of such extreme steps" 25 ; mobilising the "model voter registration poll" to demonstrate Minnesotans do not want further government intrusion in their lives" ${ }^{25}$; creating an information campaign to convince Minnesota taxpayers that numerous national programmes were already addressing this issue (that is, non-smoking among youth) and indicating "that local efforts are duplicative, a waste of taxpayers money and unnecessary"25; and using statements by Governor Rudy Perpich (D) to argue that anti-regulation statements he made indicated that he opposed smoking regulations and did not believe that "any new anti-smoking measures should be aimed at young people in school". ${ }^{25}$ Governor Perpich was not a friend of the tobacco industry; his statements were taken out of context.

Fifth, industry representatives befriended key Department of Health personnel to gain advance knowledge of implementation developments of the Minnesota Plan. ${ }^{29-31}$ Key Department of Health staffers (Mark Skubic, administrative assistant to Commissioner Ashton, and Daniel McInerney, Assistant Commissioner) appear to have extended substantial access to tobacco lobbyists. ${ }^{29}$ Tobacco lobbyists reported that Mark Skubic, a smoker at that time, had a "close relationship" ${ }^{32}$ with contract lobbyist William McGrann, and that Dan McInerney was a "personal friend" 32 of McGrann's.

\section{Legislative developments toward enacting the Minnesota Plan}

In March 1985, the Minnesota legislature introduced the Omnibus Nonsmoking and Disease Prevention Act (Omnibus Act), a multifaceted act intended to improve the sewers in Minneapolis/St Paul and to fight tobacco use. Although the Omnibus Act was essentially a tax decrease package, it included a 7 cent increase in cigarette taxes (which would have increased the tax from 18 cents to 25 cents). A number of other anti-smoking initiatives were proposed separately (health warnings on smokeless tobacco products, employer compliance assistance with the Minnesota Clean Indoor Air Act, and school curriculum changes to discourage smoking), but few of these additional initiatives were enacted.

\section{The tobacco industry's tactics}

The tobacco industry's response to the Omnibus Act illustrates three tactics used to fight the 7 cent tax increase.

The industry used its experienced contract lobbyists to stimulate procedural fights in the Legislature to kill the legislation without having to debate its merits. ${ }^{33}$ They moved the Omnibus Act proposal from committee to committee so it would miss the 4 April 1985 deadline for final committee clearance and subsequent floor debate. For example, in the House, the industry wanted to re-refer the proposal away from the Health Committee, which was not sympathetic to its interests, to the Education, Appropriations, and Tax Committees. Tobacco industry lobbyists did not want to engage in any floor debates because that meant revealing themselves and forcing legislators to take a public position in support of the industry. The tobacco industry mobilised Minnesota smokers and industry employees to oppose the Act. For example, before the Senate Finance Committee hearing, RJ Reynolds mobilised Minnesota smokers by mailing postcards pre-addressed to Senators on the committee expressing opposition. ${ }^{34}$ Philip Morris mobilised employees to call or write their legislators- 


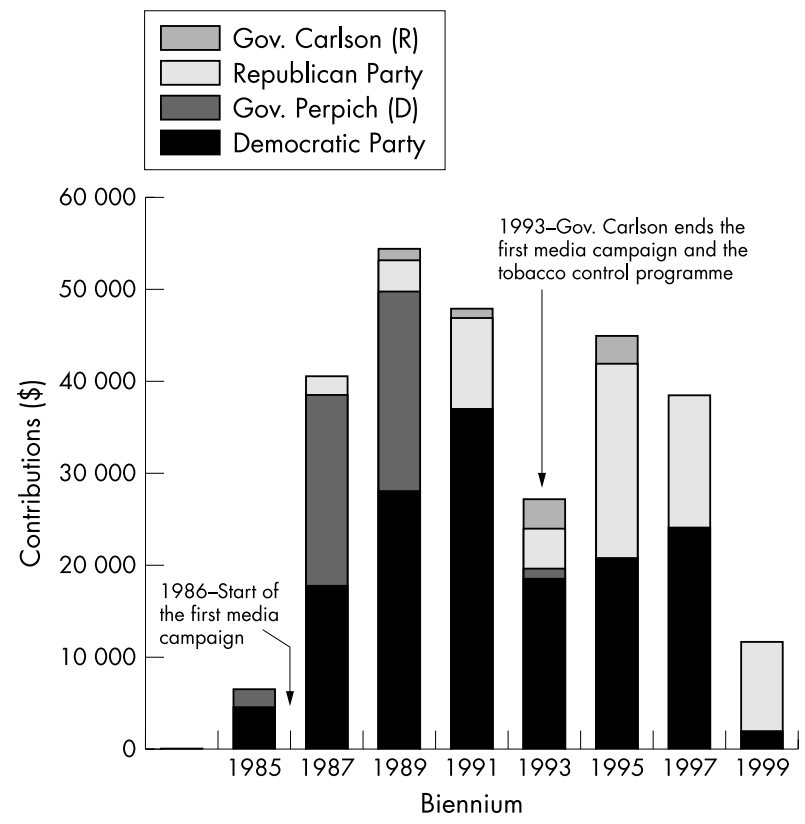

Figure 1 Tobacco industry campaign contributions. ${ }^{68-70}$ Corporate contributions are prohibited in Minnesota. Instead, lobbying organisations and political action committees (PACs) made contributions to political parties' candidates through individuals. Tobacco companies and tobacco organisations whose lobbyists made individual contributions included the following: Minnesota Candy and Tobacco Distributor Association, Northwest Candy and Tobacco Distributors Association, North State PAC, Philip Morris, RJ Reynolds, Tobacco Institute, Brown and Williamson, Smokeless Tobacco Council, SuperValu Stores, Cigar Association of America, and Pipe Tobacco Council.

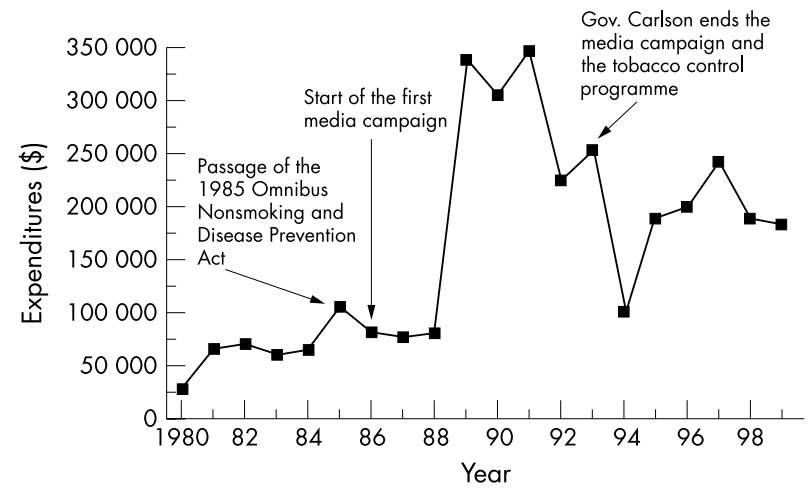

Figure 2 Tobacco industry lobbying expenditures in Minnesota, $1980-1999 .{ }^{25} 5371-86$

without being identified as a Philip Morris employee-to oppose the bill because it violated smokers' rights and imposed excessive taxation on cigarettes. ${ }^{35-38}$

A third tactic was to use campaign contributions to influence the legislative outcome of the 1985 Omnibus Act proposal. During the 1985-86 legislative session, through its contract lobbyists in Minnesota, the industry contributed $\$ 1750$ to the Republican Party and about $\$ 4800$ to the Democratic Party (fig 1). Moreover, in 1985 the Tobacco Institute budgeted $\$ 63000$ for its chief Minnesota contract lobbyist (Thomas Kelm) as well as additional funds for the two Minnesota tobacco wholesale trade groups (Minnesota Candy and Tobacco Distributors Association, and Northwest Candy and Tobacco Distributors Association) for lobbying purposes ${ }^{39}$ (fig 2).

Despite these efforts, the industry lost; the 1985 Omnibus Act passed.
The health advocates' response

Three groups of health advocates-the newly formed Minnesota Coalition for a Smoke-Free Society 2000 (Coalition), the Association for Nonsmokers Rights (ANSR), and the Minnesota Medical Association (MMA) — supported the 1985 Omnibus Act. ${ }^{40}{ }^{41}$ In May, five days before the special legislative session that considered the Omnibus Act, the MMA and the Coalition held a press conference to announce support for a separate 1 cent cigarette tax increase for non-smoking programmes and distributed 500 signed petitions to the Legislature to pass it. ${ }^{42}$

Additional supporters included state and local American Lung Association chapters and the Minnesota Medical Association Auxiliary. Since the cigarette tax increase was linked to the construction of sewer projects and non-smoking programmes, the health groups formed alliances with groups promoting pollution control, maternal and child health programmes, lead poisoning monitoring, and mosquito control, all of whom were destined to receive funds from the cigarette tax increase. ${ }^{34}$

\section{The final Bill emerges as the Omnibus Act}

On 18 May 1985, the Minnesota Senate voted 36-28 to pass the 7 cent cigarette tax with 1 cent dedicated to tobacco control. However, on 20 May, the last day of the legislative session, the House twice rejected the 6 cent tax increase for sewer projects, but passed the 1 cent tax increase for tobacco control programmes on a 96-39 vote. On 21 May, since the Senate and the House versions of the bill differed, Governor Perpich called for a special legislative session, ${ }^{43}$ which approved a compromise Omnibus Act, which included a 5 cent cigarette tax increase to fund both sewer construction (4 cents) and tobacco control programmes ( 1 cent). ${ }^{44}$

The Act promoted non-smoking through mass media, school programmes, assistance to employers to comply with Minnesota's Clean Indoor Air Act, and grants to local health departments for community programmes (Laws of Minnesota for 1985, First Special Session, chapter 14, article 19, section 15). All of these provisions were based on the Advisory Committee's recommendations.

The 1985 Omnibus Act generated about \$1.5 million/year (or $\$ 0.37$ per capita/year) for non-smoking programmes during the first five years, of which about $\$ 500$ 000/year (or $\$ 0.12$ per capita/year) was dedicated to the anti-smoking media campaign. A major objective of these funds was the reduction of smoking among Minnesota youth by 30\%, from 18\% in 1986 to $13 \%$ in $1990 .^{45-47}$

\section{Implementation of the anti-smoking media campaign} The anti-smoking media campaign included radio, television, and print media. Advertisements, directed at male and female teenagers and at young adult females, demonstrated the social undesirability of smoking by using images of youth in non-confrontational settings. These advertisements reached $71-94 \%$ of the targeted population in surveys taken between 1986 and $1989 .{ }^{45-47}$ From 1986 to 1989, while the tobacco control programme was fully funded, the adult smoking prevalence rate dropped $4.1 \%$ (from $25.1 \%$ to $21.0 \%$ ), while the rest of the US experienced a decrease of only $2.3 \%{ }^{48}$ From 1986 to 1991, smokeless tobacco use among youth decreased from $9 \%$ to $3 \%$.

\section{The tobacco industry's tactics after the passage of the Omnibus Act}

Even though the anti-smoking media campaign of the Minnesota Plan's Omnibus Act almost met the original objectives (reduction of youth smoking rates by $30 \%$ by 1990), ${ }^{46}$ the campaign was eliminated. The tobacco industry continued fighting to defeat the implementation of the 1985 Omnibus Act. The industry knew that the Minnesota Plan was a long 
range plan, so it adapted its strategy by fine tuning its tactics of framing tobacco control issues in terms of economics, government intrusion into individual rights, and excessive regulation. ${ }^{25}$

Phillip Morris recruited Minnesota smokers to fight the Democratic Governor Rudy Perpich's proposed new cigarette tax hike of 18 cents in 1987. They distributed form letters and stamped envelopes to Minnesota smokers to mail to their legislators to protest the tax hike. The letters contained a variety of messages with the names and addresses appearing on different locations on the letterhead using different coloured papers to give the impression that they were independently written letters. State Representative Wes Skoglund (DFL, District 61B) exposed the fact that Philip Morris was behind this letter writing campaign. ${ }^{49}$ The proposed cigarette tax increase was passed in June 1987 as a 15 cent increase.

A new tactic, beginning in 1988, was the successful recruitment of new allies within specific legislative districts to build up grass roots political opposition to the Minnesota Plan and its anti-smoking media campaign. ${ }^{50}$ Industry allies came from several Minnesota business and labour organisations. Michael Brozek, Tobacco Institute regional vice president, reported to his superiors that "our increasingly successful relationship with the Minnesota Grocers Association and our efforts in working with community groups (Iron Range Food Shelf Charities) are two new areas of real potential for the 1988 legislative year". ${ }^{50}$ Brozek reported additional support came from labour: "Never before has the tobacco industry embarked on such a detailed labor effort in the state of Minnesota. We have already met with officials from the Minnesota Teamsters Union, Minnesota AFSCME [American Federation of State, County, and Municipal Employees] organization and parties extremely close to leadership in the entire Minnesota labor movement and are receiving a positive response particularly in the areas of smoking restrictions and their effect on the collective bargaining process." ${ }^{50}$

In pursuing this strategy, the industry was neutralising many of the constituencies that the original Technical Advisory Committee on Nonsmoking and Health was designed to recruit into tobacco control. Neither the Department of Health nor the tobacco control advocates appear to have worked to hold these constituencies as the tobacco industry pursued them.

The tobacco industry used these allies to target legislative districts of specific House and Senate leaders. According to Brozek, targeting methods included: "Media support activity in legislative districts with an emphasis on business, social, labor, and civic groups; Labor-related interactions, where applicable, in legislators' home districts; . . . Serious and accountable interaction with non-industry persons 'aggrieved' by punitive or restrictive actions on their working conditions." ${ }^{\prime \prime 0}$ Using these allies and continuing to frame tobacco control issues primarily as tax issues, the tobacco industry inflicted substantial damage to tobacco control policymaking in Minnesota, and specifically the long term implementation of the Minnesota Plan and its media campaign. The tobacco industry also intensified its campaign contributions (fig 1) and lobbying budget (fig 2) after the start of the first media campaign in 1986. For example, it contributed \$21 815 to Governor Perpich's re-election campaign during 1989-90, the largest contribution to the campaign (1990 was an election year in Minnesota). It had also contributed \$20 905 in 1987-88. On average, whereas the tobacco industry spent about $\$ 63000 /$ year for lobbying between 1980 and 1985, it spent more than three times as much while the first media campaign was in full swing (1987-1992), averaging about \$230 000 annually (fig 2).

\section{The industry begins to make progress: the first tobacco control budget cuts}

The tobacco industry's increased campaign contributions and lobbying expenditures began to have an effect in 1990 under
Governor Perpich, when the legislature cut the tobacco control programme's budget by a third, from $\$ 1.5$ million to $\$ 1$ million. ${ }^{47}$ The governor used the State Health Department's successes in reducing the rate of smoking to recommend the cut in order to "meet the state budget shortfall and to pay for drug-prevention efforts". ${ }^{51}$ In 1991, Governor Perpich cut the programme's budget (his last budget as Minnesota governor) by nearly half a million dollars. The assistant commissioner of health, Mick Finn, observed that the state will "spend \$1.1 million next year (i.e., 1991) on non-smoking programmes even if the \$473 000 cut goes through" and argued that "under budget circumstances it made sense". ${ }^{51}$ Governor Perpich's budget reduction of an effective tobacco control programme compromised both the integrity and the legitimacy of the programme and also paved the way for further assaults on it.

\section{Elimination of the tobacco control programme by \\ Governor Carlson}

During the 1990 gubernatorial race, Republican Arne Carlson defeated Democrat Perpich. From the 1989-90 biennium election cycle to the 1993-94 biennium election cycle, Arne Carlson's campaign committee received nearly $\$ 5000$ from tobacco industry contributions (fig 1). More significantly, during the 1993-94 election cycle, at least three known Tobacco Institute contract lobbyists (Ronald Jerich, Tom Kelm, and Allen M Shofe) became fundraisers for Carlson's re-election campaign committee. $^{52}$ Tom Kelm alone expected to raise at least $\$ 10000 .^{52}$ In addition, in 1993 the tobacco industry spent over $\$ 250000$ lobbying against tobacco control measures in Minnesota (fig 2). In 1994, Tom and Doug Kelm's firm North State Advisors, the chief tobacco industry contract lobbyists in Minnesota, received at least $\$ 100000 .^{53}$

Three years after his election, Governor Carlson eliminated the anti-smoking media campaign. Later he vetoed new antitobacco legislation, including two 1994 bills that would have created a \$250000 campaign to protect children from exposure to secondhand smoke. ${ }^{54}$ Carlson justified these vetoes with claims that the state was in fiscal crisis.

In fact, there was no fiscal crisis. Governor Carlson and the Democratically controlled legislature were fighting over the size of the state's reserve fund and the size of possible tax rebates. The Minneapolis Star-Tribune reported that "the more Carlson cuts DFL [Democratic Farm Labor Party] spending and diverts the money into the reserve, the larger the political weapon he would have at his disposal in $1994 \ldots$. even by the Carlson administration's own calculations, the state will be sitting on a sizable nest egg at the end of the two-year budget cycle that runs until June 1995.",55

\section{The health advocates' failure to respond}

Fearing the weight of the fiscal crisis claims, health groups lost confidence in justifying the anti-smoking campaign. They felt that the claim of a fiscal crisis was so strong that they did not have any sympathetic support in the legislature, and therefore they could not have done anything to save the anti-smoking campaign. ${ }^{56}{ }^{57}$ There was no evidence, either in media reports, the tobacco industry documents, or from the interviews we conducted, to suggest that the health advocates challenged the claim of fiscal crisis.

The campaign also had a very low priority in the Department of Health, which was not willing to fight for it either in the Legislature or administration, and the health groups did nothing to press the Department to give the programme higher priority. The Department's actions were surprising since the tobacco control campaign represented a small fraction of the Department's budget-the media campaign ran on an annual average budget of about $\$ 500000$, compared with the Department of Health's \$75 million annual budget-since the campaign had been demonstrated to be effective. In particular, the US Centers for Disease Control and 
Prevention concluded that while the Minnesota Plan, including the first anti-smoking media campaign, was in place ( 1985 to 1992), "the state's per capita tobacco consumption declined $26 \%$, a steeper decline than the national average" ${ }^{\prime 58}$ By comparison, after the programme was dismantled, during the 1993 to 1997 period, per capita consumption in Minnesota increased $3.1 \%$, whereas the national rate decreased..$^{58}$

\section{DISCUSSION}

The first anti-smoking media campaign in Minnesota and in the USA emerged because in the early 1980s the Department of Health placed tobacco use and its health effects on the very top of its priority list. The Department of Health did a thorough job of researching this topic in the planning phase of the campaign and also involved a wide range of Minnesota based health, advocacy, business, and labour experts, as reflected in the composition of the Advisory Committee.

However, the first anti-smoking media campaign, and the entire Minnesota Plan, was compromised during the implementation phase. Three major factors led to the termination of the first anti-smoking media campaign: the tobacco industry's extensive financial resources and powerful influence on state level policy making; the Department of Health's policy inexperience with the implementation of tobacco control programmes; and health advocates' unwillingness to question political authority and political claims. Despite the fact that the original Advisory Committee was constructed to broaden the political constituency for tobacco control in Minnesota, the health groups failed to maintain these alliances or critique claims of fiscal crisis and defend the programme based on its demonstrated success.

The tobacco industry adapted quickly to the threat posed by the emergence of the Minnesota Plan and anti-smoking media campaign. Through the mobilisation of contract lobbyists in Minnesota, the industry was able to gain substantial access to and early knowledge of the new anti-smoking programme. Industry lobbyists and consultants organised opposition to all anti-smoking legislation at the local level and targeted the districts of key legislators. In addition, the industry searched for and made alliances with Minnesota labour and business groups, which it used as third parties to fight the tobacco control campaign on its behalf under the guise of excessive taxation and government interference with individual rights to smoke, while systematically avoiding the health question. The industry used an extensive political contributions programme to Minnesota based political parties and the campaigns of two governors totalling over \$175000, and an aggressive lobbying war chest of over \$2 million to fight the media campaign by indirectly diverting its funds to other programmes. The industry's fight against the first media campaign served as a testing ground for the creation of a template to fight similar programmes that arose later in other states. ${ }^{2} 759$

Despite its innovative planning, the Department of Health did not develop the political infrastructure necessary to support the programme over the long term. Instead, the Department allowed tobacco lobbyists, but not health advocates, substantial access to its anti-smoking operations. While the strategy of tying the funding of the tobacco control campaign to a major sewer project was able to bring non-health advocacy groups (environmental, housing development, and construction) that are often more sophisticated and willing to take political risks than the health groups into the effort to secure funding for the programme, there was no effort to maintain this broader coalition. Instead, the coalition contracted back to the weak and timid health voluntaries represented by the Smokefree Coalition that never questioned either the politicians' claims of fiscal crisis or pressed the Department to support the programme more strongly.
When the programme was aggressively attacked by the new governor, Arne Carlson (R), based on claims of a fiscal crisis, health advocates essentially abandoned the state programme and instead concentrated on the Minnesota ASSIST programme, a federally funded programme to support local policy change that did not have a media campaign component. (The tobacco industry also successfully attacked the Minnesota ASSIST programme..$^{60}$ ) The health advocates' never questioned the political claims of fiscal crisis made by Governor Carlson and the Minnesota legislature. There was no real fiscal crisis, only a debate on the claims to state's reserve funds. However, the legitimation of these claims and the coalition's inability to question them enabled Governor Carlson and the Legislature to remove the funds dedicated to first anti-smoking media campaign's annual budget and place its funds in the state's general fund.

In contrast, in a similar situation a few years later in California, the health advocates fought back. ${ }^{2}$ When the effective media campaign to control tobacco use in California was eliminated on 10 January 1992, under the guise of a state fiscal crisis and with claims that it was ineffective, the California unit of the American Lung Association sued the governor and forced him to restore the campaign, ${ }^{214}$ and a later campaign led by the American Heart Association and Americans for Nonsmokers' Rights fully restored the programme. ${ }^{2}$ In Florida, however, health advocates also failed to mount a vigorous defence of that state's tobacco control programme, where it has been being cut despite evidence of effectiveness. ${ }^{9}$

Earlier research on tobacco control policy implementation suggested that the enactment of policy is determined by how effective political factors and processes are in translating public support for smoking restriction into legislation, and once enacted, industry will usually not interfere with its implementation and/or enforcement. ${ }^{61}{ }^{62}$ Our results contradict this later conclusion. They indicate that the tobacco industry will fight tobacco control legislation at all levels as necessary (enactment, implementation, and enforcement). Our findings also suggest that the industry worked consistently for the first five years to destroy the tobacco control campaign, despite the initial setbacks that the tobacco industry suffered. They did this through a public relations campaign and by working to mobilise third parties and allies to successfully defeat the campaign later.

There are several general lessons to be learned from the creation and destruction of the original Minnesota campaign. It is not enough to create a comprehensive tobacco control programme. State health departments and health advocates must monitor the work of the programme's critics and the tobacco industry and defend the programme. Health advocates and health departments should assume that the tobacco industry is a resourceful and capable adversary and that the tobacco industry will always seek to aggressively adapt to new regulatory environments, and prepare to fight accordingly. Health departments should be reserved in their relations with tobacco industry lobbyists and seek to fully understand the tobacco lobby in their states before they start communicating with them or sharing information beyond what they would otherwise share with the general public. While health advocates should work with the state health departments, they should maintain their independence and not allow the health department to determine their policies and agenda. Health advocates must be willing to hold health departments accountable for their action (and inaction) in tobacco control matters.

Anti-smoking campaigns in place in 2003, including campaigns funded by the Master Settlement Agreement and similar settlements, including Minnesota's MPAAT $^{57-59}$ and state funded Target Market, ${ }^{63-67}$ that were created as a result of settlement of litigation against the tobacco industry in the late 1990s, need to be vigorously defended by health advocates from politicians who seek to reduce or destroy these 


\section{What this paper adds}

Many states and some countries have mounted tobacco control programmes financed with dedicated tobacco tax revenues. These programmes are routinely attacked by the tobacco industry, particularly during difficult budgetary times when budget crises can be used to justify cutting or eliminating tobacco control programmes.

The creation and destruction of the first Minnesota tobacco control programme between 1985 and 1993 illustrates the challenges associated with creating and defending these programmes. Simply quoting evidence that a tobacco control programme is effective does not ensure its continuing survival. Claims of fiscal crisis are an effective cover for tobacco industry efforts to dismantle successful programmes (even when there is no such crisis), particularly if health advocates accept these claims and fail to mobilise political pressure to defend the programme. This story contains many lessons for tobacco control advocates who are currently defending programmes which are under attack.

programmes. It is clear that simply providing evidence of effectiveness in reducing tobacco use (and disease caused by tobacco $^{12}$ ) is not enough. The politicians attacking these programmes must be held accountable for their actions. Otherwise, these new programmes will suffer the same fate as Minnesota's original innovative and effective anti-smoking campaign and tobacco control programme.

\section{ACKNOWLEDGEMENTS}

This work was supported by National Cancer Institute Grants CA-61021 and CA-87472 and a grant from the Robert Wood Johnson Foundation.

\section{Authors' affiliations}

T H Tsoukalas, S A Glantz, Center for Tobacco Control Research and Education, Institute for Health Policy Studies, Cardiovascular Research Institute, University of California San Francisco, San Francisco,

California, USA

\section{REFERENCES}

1 Traynor MP, Glantz SA. California's tobacco tax initiative. Am J Public Health 1996;21:543-85.

2 Glantz S, Balbach E. Tobacco war: inside the California battles. Berkeley, California: University of California Press, 2000.

3 Koh H. An analysis of the successful 1992 Massachusetts tobacco tax initiative. Tobacco Control 1996;5:220-5.

4 Begay M, Glantz S. Question 1 tobacco education expenditures in Massachusetts. Tobacco Control 1997;6:213-18.

5 Ross M. Tobacco tax campaigns: a case study of two states. Washington DC: The Advocacy Institute, 1990

6 Nordhaus Research Institute. I. Smoking cessation focus groups. Southfield, Michigan; 1995.

7 Aguinaga-Bialous S, Glantz SA. Tobacco control in Arizona, 1973-1997. San Francisco: Institute for Health Policy Studies, University of California at San Francisco; 1997

8 Goldman LK, Glantz SA. The passage and initial implementation of Oregon's Measure 44. Tobacco Control 1999;8:311-22.

9 Givel M, Glantz S. Failure to defend a successful state tobacco control program: policy lessons from Florida. Am J Public Health 2000;90:762-7.

10 Healton C. Who is affraid of the truth? Am J Public Health 2001;91:554-8.

11 Goldman L, Glantz S. Evaluation of antismoking advertising campaigns. JAMA 1994:279:772-7.

12 Fichtenberg C, Glantz S. Association of the California tobacco control program with declines in cigarette consumption and mortality from heart disease. N Engl J Med 2000;343:1772-7.

13 Siegel $M$, Biener $L$. The impact of an antismoking media campaign on progression to established smoking: results of a longitudinal youth study. Am J Public Health 2000;90:380-6.

14 Balbach E, Glantz S. Tobacco control advocates must demand high-quality media campaigns: the California experience. Tobacco Control 1998:7:397-408.

15 Miller A. Designing an effective counteradvertising campaignMassachusetts. Cancer Supplement 1998;83:2742-5.
16 Levy D, Friend K. A computer simulation model of mass media interventions directed at tobacco control. Prev Med 2001;32:284-94.

17 Wakefield M, Chaloupka F. Effectiveness of comprehensive tobacco control programmes in reducing teenage smoking in the USA. Tobacco Control 2000;9:177-86

18 Bialous S, Glantz S. Arizona's tobacco control initiative illustrates need for continuing oversight by tobacco control advocates. Tobacco Control 1999:8:141-51.

19 American Cancer Society. Great American Smokeout; 2001. Accessed 28 November 2001. URL: http://www.cancer.org/ eprise...24th Great American Smokeout?sitearea=PED

20 Minnesota Department of Health. The Minnesota plan for nonsmoking and health: report and recommendations of the technical advisory committee on nonsmoking and health. Saint Paul, Minnesota; 1984.

21 Brozek M. [Memorandum to Michael Kerrigan regarding the Minnesota Technical Advisory Committee on Nonsmoking and Health]. 27 September 1984. Legacy Tobacco Documents Library. Bates No. TNJB0000249/0252. URL: http://legacy.library.ucsf.edu/cgi/ getdoc?tid=ijs42fOO\&fmt=tif\&ref=results

22 Hardy K. Interview with Theodore H. Tsoukalas, 5 December 2001.

23 Mozingo R. Confidential information on new TI program. 13 Augus 1984. Legacy Tobacco Documents Library. Bates No. TIMN 0150840. URL: http://legacy.library.ucsf.edu/cgi/ getdoc?tid=poy $82 \mathrm{fOO} \& \mathrm{fm}=$ =tif\& ref=results

24 Landman A, Ling P, Glantz SA. Tobacco industry youth smoking prevention programs protect the tobacco industry and hurt tobacco control. Am J Public Health (in press).

25 Tobacco Institute. Public relations strategies to address the Minnesoto plan for nonsmoking and health. September, 1984. Legacy Tobacco Documents Library. Bates No. TIMN0140510/0525 URL: http://legacy.library.ucsf.edu/cgi/ getdoc?tid=nia92f00\&fmt=tif\&ref=results

26 Haley M. [Memorandum to Sheila Consaul regarding Cleveland, St Paul-Minneapolis, Boston]. 11 April 1991. Tobacco Institute. Bates No. TIMN0354995. URL: http://www.tobaccoinstitute.com/ getallimg.asp? if=avtidx\&DOCID=TIMN0354995

27 Brozek M. [Memorandum to Roger Mozingo regarding Minnesota Legislative Status]. 11 April 1985. Legacy Tobacco Documents Library Bates No. TIMN0457950/7958. URL: http://legacy.library.ucsf.edu/ $\mathrm{cgi} / \mathrm{getdoc}$ ?tid=xzs42f00\&fmt=tif\&ref=results

28 Grow D. T for Teamster and T for Tobacco. Minneapolis Star-Tribune 20 May 1998; Sect. B2.

29 Skubic MA, Mclnerney D, Jr. [Letter to Thomas Kelm and David Krogseng]. 8 July 1985. Legacy Tobacco Documents Library. Bates No. TIMN 458173. URL: http://legacy.library.ucsf.edu/cgi/ getdoc?tid=srs42f00\&fmt=tif\&ref=results

30 Skubic MA. [Letter to David Krogseng/North State Advisors]. 3 July 1986. Legacy Tobacco Documents Library. Bates No. TIMN 458155 URL: http://legacy.library.ucsf.edu/cgi/ getdoc?tid=prs42fOO\&fmt=tif\&ref=results

31 Merryman W. [Memo to Ann Duffin regarding HYD trip]. 12 February 1986. Legacy Tobacco Documents Library. Bates No. TIMN0137867/7868. URL: http://legacy.library.ucsf.edu/cgi/ getdoc?tid=avc92f00\&fmt=tif\&ref=results

32 McGrann W. Minnesota, preemptive contact with state officials. 1988 Legacy Tobacco Documents Library. Bates No. 512560484/0487. URL: http://legacy.library.ucsf.edu/cgi/ getdoc?tid=ck|33d00\&fmt=tif\&ref=results

33 Moen M. Interview with Theodore H. Tsoukalas, 11 April 2001

34 Shultz JM, Moen M, Pechacek T, et al. The Minnesota plan for nonsmoking and health: the legislative experience. J Public Health Policy 1986;7:300-13.

35 Florio DJ. MN HB.810. 18 April, 1985. Legacy Tobacco Documents Library. Bates No. TIMN0457949. URL: http://legacy.library.ucsf.edu/ $\mathrm{cgi} /$ getdoc?tid=wzs42f00\&fmt=tif\&ref=results

36 Miller DE. [Memorandum to Dale J. Florio regarding Minnesota bills S 776, H. 810 and H. 849]. 8 May 1985. Legacy Tobacco Documents Library. Bates No. TIMN0457946. URL: http://legacy.library.ucsf.edu/ cgi/getdoc?tid=tzs42f00\&fmt=tif\&ref=results

37 Miller DE. [Letter to Sen. William Bellenger]. 8 May 1985. Legacy Tobacco Documents Library. Bates No. TIMN0457947. URL: http://legacy.library.ucsf.edu/cgi/ getdoc?tid=uzs42fO0\&fmt=tif\&ref=results

38 Miller DE. [Letter to Rep. John Himle]. 8 May 1985. Legacy Tobacco Documents Library. Bates No. TIMN0457948. URL: http:// legacy.library.ucsf.edu/cgi/getdoc?tid=vzs42f00\&fmt=tif\&ref=results

39 State Activities Division. Variance analysis of budgeted vs. actual expenditures, year ending December 31, 1984. 1985. Bates No. TIMS0025841/5847. URL: http://www.tobaccoinstitute.com/ getallimg.asp?if=avtidx\&DOCID=TIMS002584

40 Minnesota Coalition for a Smoke-Free Society 2000. Press Release. In. St. Paul, Minnesota; 1985.

41 Minnesota Coalition for a Smoke-Free Society 2000. Minnesota legislators protect the public health of all Minnesotans by passing omnibus nonsmoking bill. 1985.

42 Minneapolis Star-Tribune. Cigarette-tax proposal is sought for session. 1985 May 28.

43 Blake L. No agreement on increase in cigarette taxes. Minneapolis Star-Tribune 21 May 1985.

44 Wilson B. 4 cent rise in cigarette tax approved by conferees. Minneapolis Star-Tribune 31 May 1985; Sect. 1A.

45 Minnesota Department of Health. The Minnesota nonsmoking initiative, June 1985-December 1986: a report to the 1987 legislature. Saint Paul, Minnesota: Minnesota Department of Health, 1987. 
46 Minnesota Department of Health. The Minnesota tobacco-use prevention initiative, 1987-1988: a report to the 1989 Legislature. Sain Paul, Minnesota: Minnesota Department of Health. 1989

47 Minnesota Department of Health. Minnesota tobacco-use prevention initiative, 1989-1990: a report to the 1991 Legislature. Saint Paul, Minnesota: Minnesota Department of Health, 1991.

48 Anon. Smoking prevalence among selected adult demographic groups in participating states - behavioral risk surveillance system, 1986-1990. MMWR Morb Mortal Wkly Rep 1991;40(SS-4): 13.

49 Whereatt $\mathbf{R}$. State smokers recruited to help lobby against cigarette tax bill. Minneapolis Star-Tribune 29 April 1987; Sect. 4N.

50 Brozek M, Nelson DC. [Memorandum to William A. Cannell regarding Minnesota plan/status report]. 6 January 1988. Legacy Tobacco Documents Library. Bates No. TIMN0458078/8085. URL http://legacy.library.ucsf.edu/cgi/ getdoc?tid=jqs $42 f 00 \& f m t=t i f \& r e f=$ results

51 Parker W. Anti-smoking budget cut one-third. St. Paul Pioneer Press 18 April 1990; Sect. 6B.

52 Ragsdale J. Fund-raiser has foes fuming: tobacco lobbyists among sponsors of Carlson event. St. Paul Pioneer Press 4 October 1994;Sect. 1C, 4C.

53 Tobacco Institute. 1994 proposed budget. 11 December 1993. Lorillard Tobacco Co. Bates No. 91082882/2938. URL: http://www.lorillarddocs.com/ getimg.asp?pgno=0\&start=0\&if=avlidx\&bool=Did\%3A\%2091082 882\&docid $=91082882 / 2938$ \&docnum $=1$ \&summary $=0$ \&sel $1=$

54 Association for Nonsmokers Rights (ANSR). Update on tobacco bills in the Minnesota House and Senate: March 1994-May 1994. St. Paul, Minnesota: ANSR; 1994.

55 McGrath DJ. Behind the budget fight: politics and prudence. Minneapolis Star-Tribune 23 May 1993; Sect. 1B.

56 Knapp J. Interview with Theodore H. Tsoukalas, May 10, 2000.

57 Weigum J. Interview with Theodore H. Tsoukalas, May 9, 2000

58 Gordon G, Hamburger T. Minnesota no longer leads the pack; health experts cite decline in antismoking efforts. Minneapolis Star-Tribune 23 May 1999; Sect. 1B.

59 Givel MS, Glantz SA. Tobacco industry political power and influence in Florida from 1979 to 1999. San Francisco: Institute for Health Policy Studies, University of California at San Francisco, 1999.

60 Bialous SA, Fox BJ, Glantz SA. Tobacco industry allegations of "illegal lobbying" and state tobacco control. Am J Public Health 2001;91:62-7.

61 Jacobson PD, Wasserman J, Raube K. The politics of antismoking legislation. J Health Polit Policy Law 1993;18:787-819.

62 Jacobson PD, Wasserman J. The implementation and enforcement of tobacco control laws: policy implications for activists and the industry. J Health Politics Policy Law 1999;24:567-98.

63 Marcotty J, Schmickle S. Is state's teen anti-smoking group on target? Minneapolis Star-Tribune 15 April 2002.

64 Thoreau N. Target market 'hits home' with graffiti for local members. West Central Tribune 27 April 2002

65 Marcotty J. Antitobacco group, Hatch square off in legal filings. Minneapolis Star-Tribune 28 April 2002.

66 Bakst B. Tobacco group issues a challenge to Hatch. Pioneer Press 28 April 2002

67 Anon. Our view - Hatch helps tobacco's cause. Duluth News Tribune 5 May 2002.

68 Minnesota Campaign Finance and Public Disclosure Board. Registered lobbyists, associations or individuals represented, lobbying subjects, kinds of action (under Minn. Stat. Sec. 10A.02, Subd. 8, and 10A.05). St. Paul, Minnesota; 1985-2000.

69 Minnesota Campaign Finance and Public Disclosure Board. Report of receipts and expenditures for principal campaign committee. St Paul, Minnesota; 1985-2000.

70 Minnesota Campaign Finance and Public Disclosure Board. Political party committees: report of receipts and expenditures. St Paul, Minnesota; 1985-2000.
71 Tobacco Institute. The Tobacco Institute 1981 Budget, State Activities Department. 9 August 1980. Bates No. TIMS0026362/6397. URL: http://www.tobaccoinstitute.com/cgi-bin/

r...vtid $\&$ start $=80 \& \max =10 \&$ bool $=$ kelm\&summary $=0$

72 Tobacco Institute. Tobacco Institute [1982 Budget]/Tobacco Tax Council. 4 May 1982. Bates No. TIMS0026353/6361. URL: http://www.tobaccoinstitute.com/cgi-bin/ r...vtid $\&$ \&start $=80 \& \max =10 \&$ bool $=$ kelm\&summary $=0$

73 Tobacco Institute. The Tobacco Institute 1983 Budget [State Activities Division]. November 30,1982. Bates No. TIMS0026295/6297. URL: http://tobaccoinstitute.com/cgi-bin/ r...vtid $x$ \&start $=80 \& \max =10$ \&bool $=$ kelm\&summary $=0$

74 Tobacco Institute. [Tobacco Institute 1984 Budget]/State Activities Policy Committee. 18 August, 1983. Lorillard Tobacco Company. Bates No. 03676668/6759. URL: http://www.lorillarddocs.com/cgi-bin/ rsasearch.asp

75 Tobacco Institute. 1985 [Tobacco Institute] Budget: cost center, state activities division headquarters, no. 1401, account 6000, legislative counsel. 1985. Bates No. TIMSO025842/5845. URL: http://www.tobaccoinstitute.com/cgi-bin/rsasearch.asp

76 Tobacco Institute. [Tobacco Institute], State Activities Division 860000 [1986] proposed budget 850918. 18 September 1985. Legacy Tobacco Documents Library. Bates No. 680544624/4727. URL: http://legacy.library.ucsf.edu/cgi/ getdoc?tid=pvh04fO0\&fmt=tif\&ref=results

77 Tobacco Institute. The Tobacco Institute 900000 [1990] budget. 20 October 1989,1990. Bates No. 640506690/6967. URL: http://www.bw.aalatg.com/public.asp

78 Tobacco Institute. The Tobacco Institute 910000 [1991] budget. 30 October 1990. Legacy Tobacco Documents Library. Bates No. 91083521/3713. URL: http://legacy.library.ucsf.edu/cgi/ getdoc?tid=ql $\times 90 \mathrm{e} 00 \& \mathrm{fmt}=$ tif\&ref=results

79 Tobacco Institute. The Tobacco Institute 910000 [1991] budget. 30 October 1990. Legacy Tobacco Documents Library. Bates No. 91083563/3628. URL: http://legacy.library.ucsf.edu/cgi/ getdoc?tid=rlx90e00\&fmt=tif\&ref=results

80 Tobacco Institute. The Tobacco Institute 910000 [1991] budget. 30 October 1990. Legacy Tobacco Documents Library. Bates No. 91083629/3713. URL: http://legacy.library.ucsf.edu/cgi/ getdoc?tid=slx90e00\&fmt=tif\&ref=results

81 Tobacco Institute. The Tobacco Institute 930000 [1993] budget. 14 October 1992. Lorillard. Bates No. 91085541/5715. URL: http://www.lorillarddocs.com/ getallimg.asp?if=avlidx\&DOCID=91085541/5715

82 Tobacco Institute. The Tobacco Institute 940000 [1994] budget. 12 November 1993. Bates No. 91082881/3009. URL: http:// www.lorillarddocs.com/getallimg.asp?if=avlidx\&DOCID=91082882/ 2938

83 Tobacco Institute. The Tobacco Institute 1996 budget state activities division cost center national headquarters no. 1401. 24 October 1995. Bates No. TNWL0004351/4380. URL: http:// www.tobaccoinstitute.com/cgi-bin/tisearch.exe

84 Tobacco Institute. The Tobacco Institute 1997 budget [state activities division]. 9 December 1996. Bates No. TNWL0004485/4550. URL: http:www.tobaccoinstitute.com

85 Tobacco Institute. The Tobacco Institute 990000 [1999] proposed budget. 27 August 1998. Bates No. 86599530/9649. URL: http://www.lorillarddocs.com/ getallimg. asp? if $=$ avlidx\&DOCID $=86599530 / 9649$

86 Tobacco Institute. Lobbyist [Tobacco Institute 1987 Budget]. 4 January 1987. Bates No. TIMSO022453/2456. URL: http:// www.tobaccoinstitute.com/cgi-bin/ r...vtidx\&start $=80 \& \max =10 \&$ bool $=$ kelm\&summary $=0$ 